\title{
EVOLUÇÃO TECTONOESTRATIGRÁFICA DOS SISTEMAS TRANSCORRENTES CARAJÁS E CINZENTO, CINTURÃO ITACAIÚNAS, NA BORDA LESTE DO CRATON AMAZÔNICO, PARÁ
}

\section{ROBERTO VIZEU L. PINHEIRO ${ }^{1} \&$ ROBERT E. HOLDSWORTH ${ }^{2}$}

\begin{abstract}
TECTONOSTRATIGRAPHIC EVOLUTION OF THE CARAJÁS AND CINZENTO STRIKE SLIP SYSTEMS, ITACAIÚNAS BELT, EAST OF THE AMAZONIAN CRATON, PARÁ STATE The Carajás-Cinzento fault system occurs within the Itacaiúnas Belt, Amazonian Craton, Brazil. The regional tectonostratigraphy can be subdivided into: (1) the Basement Assemblage - orthogneisses, migmatites, and granulites (the Xingu and Pium Complexes; Plaquê Suite) and a later volcano-sedimentary sequence of ironstones, quartzites, amphibolites and schists (Igarapé Salobo Group). These rocks underwent intense ductile shearing and high grade metamorphism along the Itacaiúnas Shear Zone (ISZ). (2) a Cover Assemblage represented by very low-grade volcanic and sedimentary rocks, rests unconformably on the basement rocks. Older clastic, volcanic and ironstone sequences (Igarapé Pojuca \& Grão Pará Groups; ca.2.7 Ga) are overlain by a sequence of marine to fluvial deposits (Águas Claras Formation). Both Cover and Basement assemblages are intruded by ca.2.5 and ca.1.8 Ga A-type granitic plutons and basic dykes. All units are unconformably overlain by a localised sequence of polymitic conglomerates (Gorotire Formation). A subvertical EW mylonitic fabric developed in the Basement Assemblage rocks where it preserves widespread sinistrally transpressional kinematic indicators (ca.2.8 Ga). At least three cycles of Archaean to Proterozoic brittle-ductile strike-slip reactivation at low metamorphic grades appear to postdate the development of the ISZ, leading to the formation of the Carajás and Cinzento fault systems. The Cover Assemblage sequences were faulted down into dilational jogs formed during dextral displacements. The effects of a later episode of brittle-ductile sinistral transpression are preserved, localised in the region of the major fault strands. Circunstantial evidences indicate further minor fault reactivation during the Phanerozoic, and the region appears to be tectonically active in the present. There is widespread evidence that the mylonitic fabrics of the ISZ controlled the orientation of later structures. Long-term fault zone weakening is common in those regions where brittle processes caused increases in fault zone permeability allowing extensive syn-tectonic fluid circulation, some of which caused gold and copper mineralisation.
\end{abstract}

\section{Keywords: Amazonian, Serra dos Carajás, Amazonian Craton}

RESUMO O sistema de falhas Carajás-Cinzento localiza-se ao longo do Cinturão Itacaiúnas, Craton Amazônico. O quadro tectonoestratigrafico da região pode ser subdividido em: (1) Assembléia do Embasamento, que inclui ortognaisses, migmatitos e granulitos (complexos Xingu e Pium; Suite Plaquê) e uma sequiência vulcano-sedimentar (formações ferríferas, quartzitos, anfibolitos e xistos - Grupo Igarapé Salobo). Estas rochas foram afetadas por intensa deformação dúctil de alta temperatura, associada com a Zona de Cisalhanento Itacaiúnas (ZCI); (2) Assembléia de Cobertura, representada por rochas vulcânicas e sedimentares, em discordância sobre as rochas do embasamento. Rochas clásticas, vulcânicas e formações ferríferas (Grupos Igarapé Pojuca e Grão Pará; ca. 2.7Ga) estão superpostas por depósitos marinhos a fluviais (Formação Águas Claras). Tanto as rochas do embasamento quanto as de cobertura estão intrudidas por granitos tipo A de idades $c a .2 .5 \mathrm{Ga}$ e ca.1.8Ga, e diques. Estas unidades, por sua vez, estão sobrepostas localmente por conglomerados polimíticos (Formação Gorotire). Durante a formação das rochas da Assembléia do Embasamento desenvolveu-se uma foliação milonítica E-W subvertical, sob transpressão sinistral (ca.2.8Ga). Pelo menos três eventos arqueanos a proterozóicos de reativação transcorrente rúptil-dúctil, ocorreram após o desenvolvimento da ZCI. As seqüências de cobertura subsidiram em zonas de dilatação sob cinemática destral. Os efeitos de episódios posteriores de deformação transpressiva sinistral estão registrados, localmente, nas adjacências de falhas maiores. Há evidências de reativações tardias, de menor intensidade, durante o Fanerozóico e aparentemente, também no intervalo Cenozóico-Recente (neotectônica). A trama milonítica da ZCI controlou a orientação dos lineamentos Carajás e Cinzento. As fallhas atuaram como zonas de fraqueza nesta região, onde os processos de fraturamento causaram o aumento da permeabilidade das rochas, particularmente nas zonas de falhas, produzindo o ingresso de fluidos, alguns dos quais, responsáveis por depósitos de cobre e ouro, dentre outras.

Palavras-chaves: Amazônia, Serra dos Carajás, Craton Amazônico

INTRODUÇÃo O Cinturão Itacaiúnas, na borda leste do Craton Amazônico (Fig.1), tem sido alvo de pesquisas geológicas desde o fïnal da década de 60 (por ex. Barbosa et al. 1966). A maioria dos estudos geológicos realizados enfatizam principalmente às questões estratigráficas e assuntos relacionados aos depósitos minerais (Beiseigel et al. 1973, Hirata et al. 1982, Meireles et al. 1984).

Duas propostas estratigráficas importantes tornaram-se referências para os estudos da região de Carajás. Uma, de autoria da equipe da DOCEGEO (1988), baseou-se fortemente em princípios litoestratigráficos, enfatizando as rochas arqueanas, proterozóicas e fanerozóicas (Fig.2). Outra, lançada pela CPRM, publicada por Araújo \& Maia (1991), representou o primeiro passo na tentativa de organização tectonoestratigráfica das rochas da região (Fig.2).

Neste contexto, têm sido igualmente importantes os trabalhos realizados por diversos autores que, isoladamente ou em grupos, têm participado de inúmeras discussões sobre problemas gerais ou específicos da geologia desta área (Wirth 1986, Lindenmayer 1990, Machado et al. 1991, Nogueira 1995, Barros 1997, dentre outros).

Estudos enfocando a geologia estrutural e tectônica das rochas de Carajás tem sido pouco sistemáticos, a maioria abordando problemas particulares das minas (Siqueira 1990, Marçal 1991, Lab 1992).

Este trabalho apresenta uma proposta de evolução tectono-estrutural da região da Serra dos Carajás, diferente das anteriores, baseada em estudos tectônicos de detalhes em rochas que ocorrem ao longo dos sistemas transcorrentes Carajás e Cinzento.

GEOLOGIA REGIONAL - BREVE HISTÓRICO O Cinturão Itacaiúnas, localizado na parte leste do Escudo Brasil Central (Fig.1),

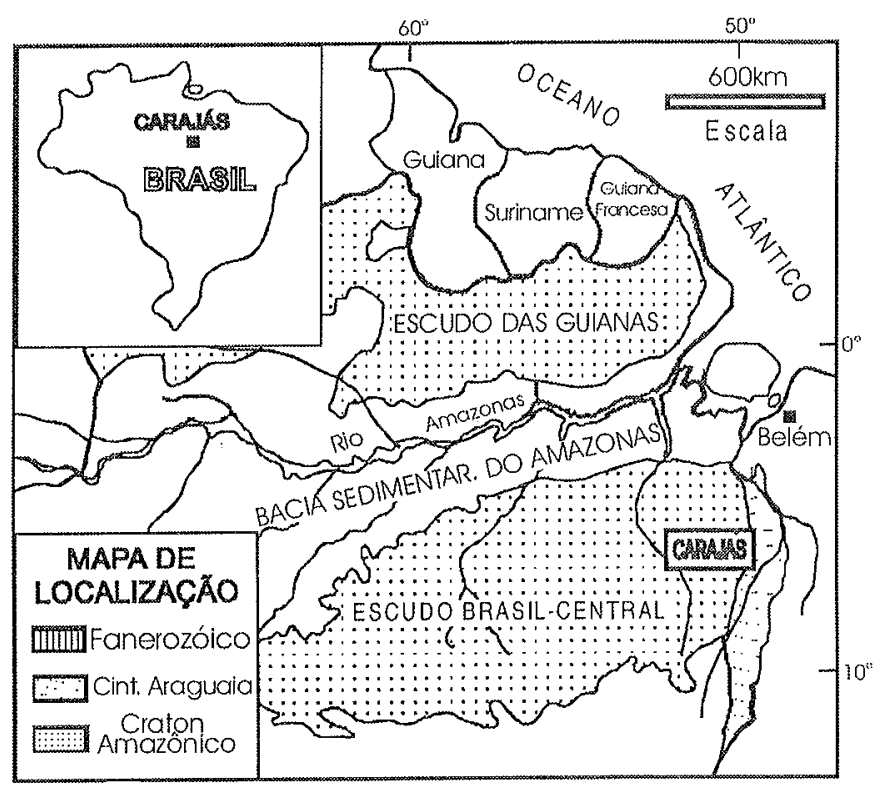

Figara I-Mapa de Localização da região estudada, no contexto do Craton Amazônico. 


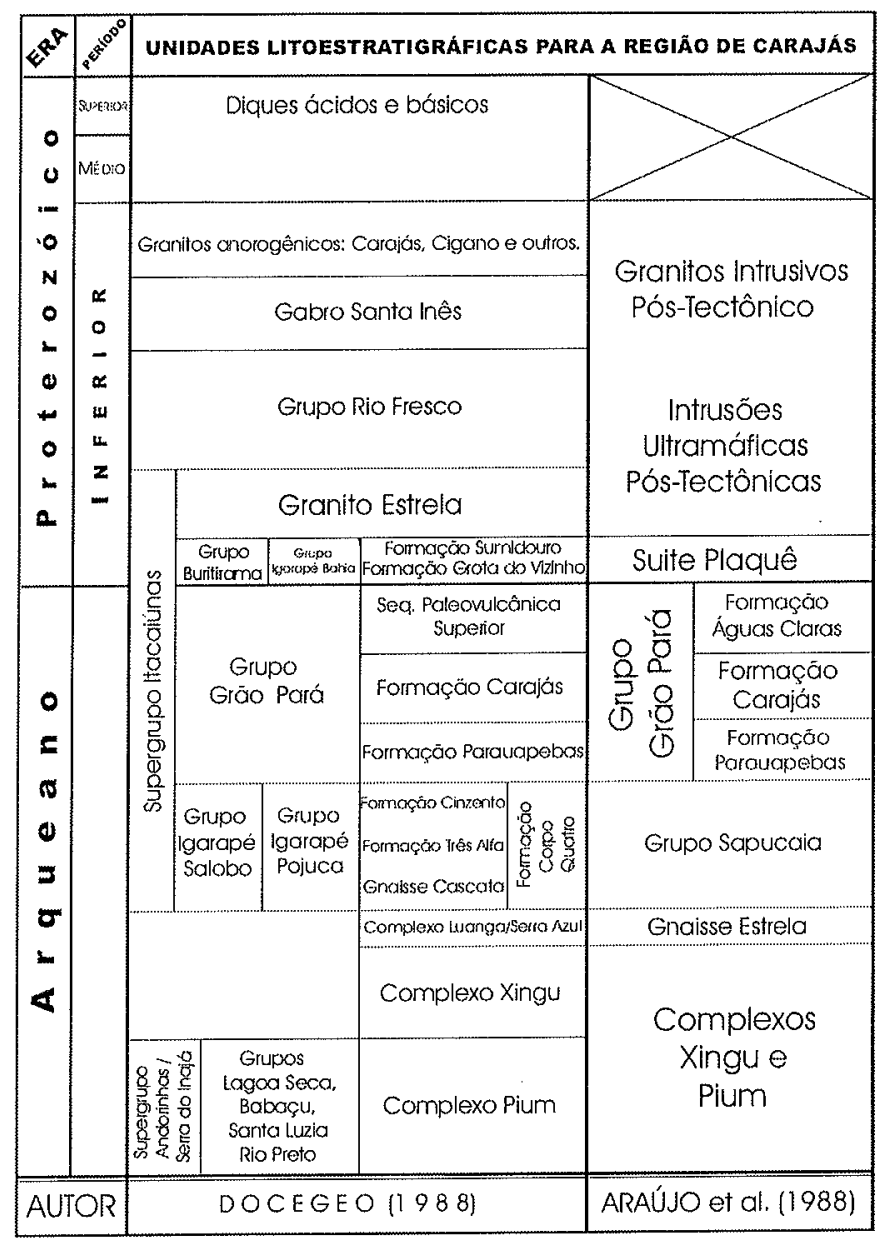

Figura 2 - Colunas estratigráficas comparativas, segundo DOCEGEO (1988) $e$ Aralijo \& Maia (199I).

é composto por feixes de estruturas orientadas na direção E-W, formando um leque imbricado de cavalgamentos oblíquos dúcteis, ao sul, e os sistemas transcorrentes Carajás e Cinzento, ao norte (Araújo \& Maia 1991). Esse cinturão é cortado a leste pelo Cinturão Araguaia (Proterozóico Superior), e a oeste pela chamada Província Proterozóica. Seu limite sul com o Terreno Granito-Greenstone de Rio Maria (Arqueano) é provavelmente transicional (Ferreira 1993). Ao norte está encoberto por rochas paleozóicas da Bacia Sedimentar do Amazonas e sedimentos cenozóicos.

A porção norte do Cinturão Itacaiúnas (Fig.3), formada pelos sistemas transcorrentes Carajás e Cinzento, é marcada por fortes lineamentos, cortando rochas arqueanas dos complexos Pium e Xingu, granitos arqueanos da Suite Granítica Plaquê (Araújo \& Maia 1991) e rochas vulcânicas e sedimentares, metamorfisadas ou não, dos grupos Igarapé Salobo, Igarapé Pojuca, Igarapé Bahia, Grão Pará (DOCEGEO 1988) e do Grupo Rio Fresco (DOCEGEO 1988), este último posteriormente denominado de Formação Águas Claras (Araújo \& Maia 1991, Nogueira 1995, Fig.2). Essas unidades estão intrudidas por granitos de idades próximas a $2.5 \mathrm{Ga}$ (Complexo Granítico Estrela - Barros 1997 Granito Old Salobo - Lindenmayer 1990) e 2.0-1.8 Ga (Gibbs et al. 1986, Machado et al. 1991), estes últimos reconhecidos em todo o Craton Amazônico (Dall'Agnol et al. 1987). A história pósMesoproterozóico das rochas da região é ainda pouco conhecida.

A importância de fluidos hidrotermais na alteração das rochas e na concentração de depósitos minerais tem sido enfatizada, por exemplo por Medeiros Neto (1985), Lindenmayer (1990), e outros.

A estruturação das rochas ao longo do Sistema Transcorrente Carajás foi originalmente reconhecida como formando um sinclinório com eixo caindo para $\mathrm{E}$ e W, cortado longitudinalmente pela Falha Carajás (Meireles et al. 1984). Essa idéia, que descreve uma estruturação com mergulho convergente das camadas nas abas norte $\mathrm{e}$ sul da região de Carajás, permaneceu única por quase 19 anos até que Araújo \& Maia (1991),sugerissem um modelo tectônico em flor positiva, desenvolvido por transpressão.

O modelo de Araújo \& Maia (1991), enfatiza uma evolução tectonoestratigráfica para a região onde o embasamento seria formado por rochas granulíticas do Complexo Pium (3.0 Ga, U/Pb em zircão; Rodrigues et al. 1992) e do Complexo Xingu (2.8 Ga, U/Pb em zircão, Machado et al. 1991), além de granitos estratóides (Suite Granítica Plaquê) e o Gnaisse Estrela (2.5 Ga, Rb/Sr, Barros 1991), este último reestudado posteriormente em detalhe por Barros (1997).

De acordo com o modelo proposto, esses conjuntos litológicos teriam sido envolvidos em um episódio transtensivo destral arqueano responsável pelo desenvolvimento de bacias isoladas controladas pela geometria anastomosada dos lineamentos principais. Cada bacia seria preenchida por depósitos vulcânicos e/ou sedimentares de forma independente. Na bacia de Carajás, em particular, teriam sido depositadas as rochas dos grupos Grão Pará (sentido de Rêgo 1933) e Igarapé Pojuca e da Formação Rio Fresco, anteriormente descritas pela DOCEGEO (1988). As rochas do Grupo Rio Fresco foram denominadas Formação Águas Claras, com idade arqueana, fazendo parte do topo do Grupo Grão Pará (Fig.2).

Ao longo do Sistema Transcorrente Cinzento teriam se instalado rochas vulcânicas e rochas sedimentares clásticas, bem como formações ferríferas, associadas ao Grupo Igarapé Salobo. Rochas vulcânicas e sedimentares, expostas na terminação em "rabo-de-cavalo" na região de Serra Pelada, representariam frações de rochas remanescentes do chamado Greenstone Belt de Rio Novo (DOCEGEO 1988).

O Sistema Transcorrente Cinzento foi descrito por Siqueira (1990) com sendo composto pelo Duplex Salobo, o Romboedro Cururu e o Duplex de Serra Pelada. A evolução tectônica desse lineamento compreenderia um evento destral capaz de individualizar bacias transtensivas posteriormente invertidas sob regime de colisão oblíqua dúctil (Siqueira 1990). Esse episódio de inversão teria afetado também as rochas da parte sul do Cinturão Itacaiúnas, gerando leques imbricados de cavalgamentos oblíquos, e seria responsável pela reativação sinistral, sob transpressão, das estruturas dos sistemas transcorrentes Carajás e Cinzento (Araújo \& Maia 1991).

As rochas vulcânicas e sedimentares depositadas no Duplex do Salobo (Siqueira 1990) teriam sido metamorfisadas dinamicamente durante inversão transpressiva sinistral dúctil, na fácies granulito a anfibolito $_{2}$ dando origem às rochas do Grupo Igarapé Salobo (xistos, formações ferríferas, quartzitos, metavulcânicas). As rochas depositadas na terminação em "rabo-de-cavalo" do Sistema Transcorrente Cinzento teriam sido da mesma forma invertidas, porém alcançando somente grau metamórfico xisto verde (Siqueira 1990).

Os granitos Central da Serra dos Carajás, Cigano, Young Salobo dentre outros com idade radiométrica em torno de $1.9 \mathrm{Ga}$ (Wirth et al. 1986, Lindenmayer 1990), intrudiram em diversas rochas da região.

HISTÓRIA TECTÔNICA - PROPOSTA ATUAL Deformação de Alta temperatura Os gnaisses tonalíticos e granodioríticos, granitos, granulitos, anfibolitos, quartzitos, xistos e rochas ferríferas do Complexo Xingu, Complexo Pium, Grupo Igarapé Salobo e Suite Granítica Plaquê são caracterizados por uma importante trama milonítica de alta temperatura (DOCEGEO 1988, Araújo \& Maia 1991, Macambira et al. 1994). Essas rochas estão presentes tanto a sul do Cinturão Itacaiúnas, formando um leque imbricado de cavalgamentos oblíquos dúcteis (Araújo \& Maia 1991), como na região do Igarapé Salobo (DOCEGEO 1988, Costa et al. 1995). Estão dispostas ao longo de zonas de cisalhamento anastomosadas E-W, contornando lentes de rochas heterogeneamente deformadas. A idade dessas zonas de deformação tem sido atribuída a cerca de $3.0 \mathrm{Ga}$ a $2.8 \mathrm{Ga}$ (Machado et al. 1991, Rodrigues et al. 1992). O metamorfismo presente nestas rochas alcançou as fácies granulito a anfibolito alto.

Estas rochas, caracterizadas pela presença dessa trama de alta temperatura, são aqui reunidas na Assembléia do Embasamento e associadas a um episódio de deformação dúctil (Cinturão de Cisalhamento Itacaiúnas - Arqueano).

A Assembléia do Embasamento foi afetada por transpressão sinistral, com a deformação produzindo sistemas de transcorrências dúcteis e zonas de cisalhamento dominadas por cavalgamentos oblíquos (Araújo \& Maia 1990, Costa et al. 1995). Estudos recentes mostram a presença marcante da foliação milonítica associada a uma lineação de estiramento mineral e confirmam a geometria sinistral des- 

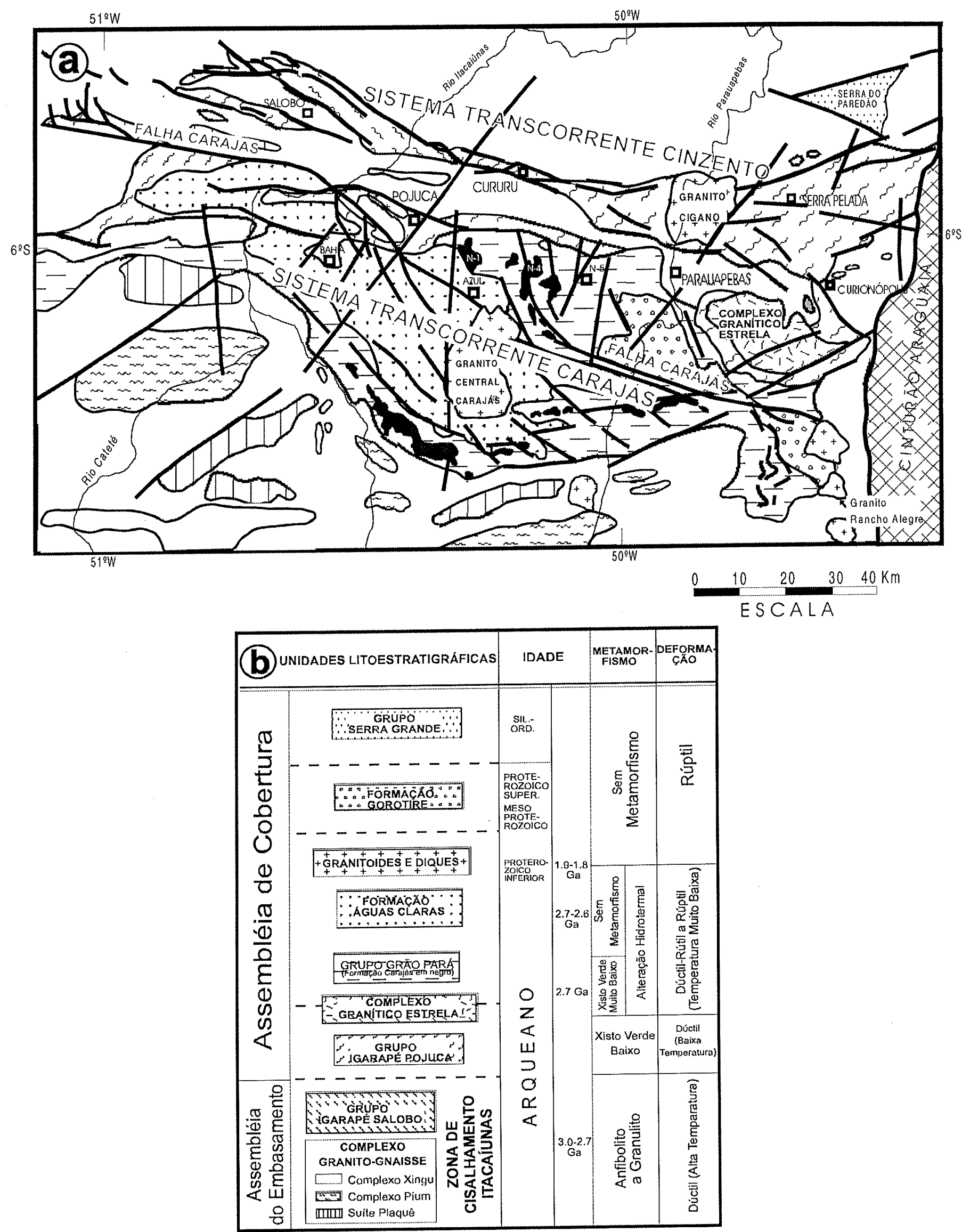

Modificado de Pinheiro (1997) 
sa trama. No entanto, a história cinemática dessas zonas de deformação tem se mostrado bem mais complexa do que a indicada em trabalhos anteriores (Siqueira 1990). Uma das seções mais representativas dessa complexidade pode ser vista ao longo do Rio Itacaiúnas, onde afloram rochas granitóides atribuídas ao Complexo Xingu (Fig.4). A foliação milonítica presente nessas rochas mostra uma orientação geral NW-SE, com mergulhos moderados a fortes para NE (Fig.4). A deformação é heterogênea, sendo possível se definir domínios marcados por diferentes orientações e penetratividade da trama deformacional planar e linear, implicando padrões cinemáticos distintos. A orientação da lineação é bastante variável dentro desses domínios (Fig.4). Em determinado domínio podem ser encontrados padrões indicativos tanto de cinemática destral quanto sinistral, com o predomínio de uma ou outra. Em todos os pontos estudados destaca-se uma significante componente reversa associada à uma cinemática transcorrente sinistral, onde o bloco SW representa o teto. Não é possível se observar qualquer relação de superposição de tramas e tampouco pode-se comprovar que os conjuntos destrais e sinistrais formam pares conjugados. Esse mesmo padrão cinemático sinistral heterogêneo e complexo pode ser observado nas rochas do embasamento aflorantes a leste do Rio Parauapebas, ao sul da Serra do Rabo e ao norte de Serra Pelada (Fig.3)

A presença desse complexo arranjo geométrico-cinemático é consistente com um regime transpressional com intensa partição temporal, geométrica e cinemática da deformação tal como em outras zonas transpressivas similares (Fossen \& Tikoff 1993).

Deformação Dúctil de Baixa Temperatura: O Grupo Igarapé Pojuca As rochas metassedimentares do Grupo Igarapé Pojuca afloram principalmente na região do Cururu, em Serra Pelada e na borda norte do conjunto de falhas que deformaram o Sistema
Transcorrente Carajás, estendendo-se em direção à Serra do Rabo, ao sul de Curionópolis (Fig.3).

Essas rochas mostram predominantemente uma clivagem ardosiana mergulhando com ângulos moderados a fortes, impressas em rochas pelíticas e vulcânicas (por ex.: Serra Pelada, Igarapé Bahia, Igarapé Pojuca), e trama protomilonítica a milonítica de baixa temperatura em quartzitos (por ex.: Cururu, Rio Itacaiúnas). Tanto a textura deformacional quanto as assembléias minerais observadas nessas rochas são consistentes com metamorfismo regional de fácies xisto verde baixo, embora os efeitos tardios de importantes eventos hidrotermais regionais tenham produzido substanciais alterações nas características mineralógicas e texturais dessas litologias (Araújo \& Maia 1991)

A relação estratigráfica entre essas rochas e aquelas do Grupo Grão Pará são ainda incertas em grande parte devido à falta de exposições dos contatos (Medeiros Neto 1985, Lindenmayer 1990). É possível que as rochas do Grupo Igarapé Pojuca, ou parte delas, sejam produtos de metamorfismo termal sobre rochas do Grupo Grão Pará (Barros 1997). Pode-se sugerir, no entanto, que os dois grupos constituem unidades separadas por discordância, baseando-se no fato de que as rochas do Grupo Igarapé Pojuca são pervasivamente deformadas e mostram trama tectônica e assembléias minerais de temperaturas mais altas que aquelas do Grupo Grão Pará.

As rochas do Grupo Igarapé Pojuca, nas regiões do Igarapé Bahia e Serra Pelada, estão dobradas isoclinalmente em várias escalas e densamente cortadas por falhas. Em Serra Pelada, as dobras apresentam uma predominante clivagem transversa (transecting cleavage; Johnson 1991) horária, consistente com deformação transpressiva sinistral ( $\mathrm{Pi}$ nheiro \& Holdsworth 1995, 1997b) presumivelmente tardia àquela associada ao Cinturão de Cisalhamento Itacaiúnas, e formada sob temperatura mais baixa em relação aquela das rochas do embasamento.

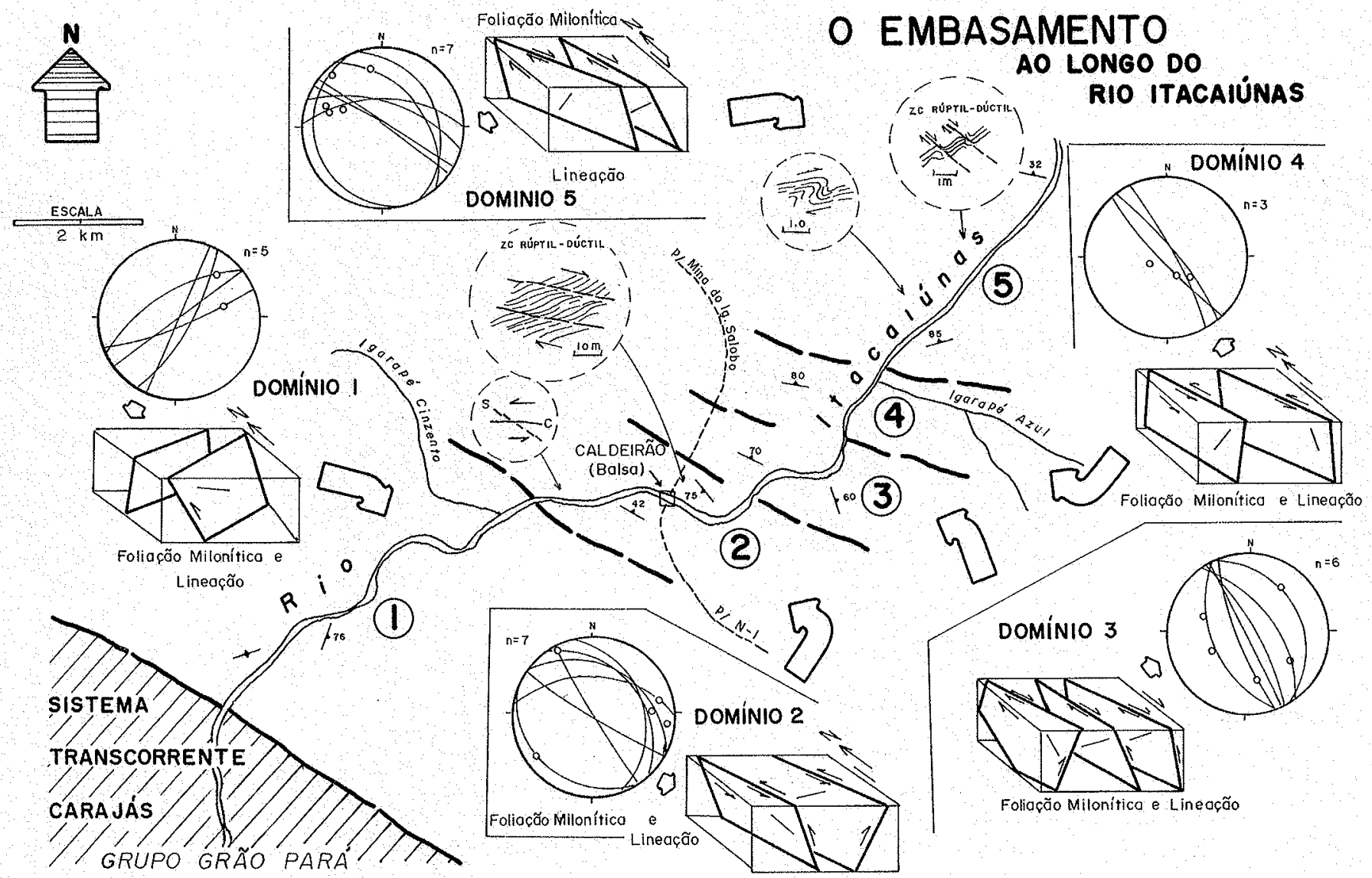


Os Sistemas Transcorrentes Carajás e Cinzento Um evento de reativação regional rúptil tardio afetou a trama dúctil do embasamento (ca.2.8Ga), promovendo o desenvolvimento de dois feixes E-W maiores de falhas, facilmente observados em sensores remotos: o Sistema Transcorrente Carajás e o Sistema Transcorrente Cinzento (Fig.3). Essas estruturas, com ângulos de mergulhos altos, mostram em planta uma geometria curva, anastomosada, típica de zonas de falhas transcorrentes. Esse arranjo geométrico complexo expõe evidências, em campo (indicadores cinemáticos), de movimentação tanto destral quanto sinistral, iniciadas provavelmente em cerca de $2.7 \mathrm{Ga}$ (posterior ao evento dúctil principal; quando da implantação da Bacia do Grupo Grão Pará).

As orientações e a geometria das falhas que compõem esses sistemas são fortemente controladas pela posição espacial e geometria da trama dúctil das rochas da Assembléia do Embasamento subjacentes. A orientação das estruturas rúpteis presentes no embasamento, em escala de afloramento, é variável, porém removendo-se deste conjunto as fraturas N-S e NE-SW observa-se que as demais mostram as mesmas orientações da fábrica milonítica, isto é, E-W a WNW-ESE. Os conjuntos N-S e NE-SW são atribuídos ao Proterozóico Médio a Superior:

Exemplos de paralelismo entre as tramas dúcteis e rúpteis, em afloramentos, são comuns. Em escala regional, as rochas vulcânicas e sedimentares aflorantes, aqui referidas como rochas da Assembléia de Cobertura (Fig.3), estão claramente associadas com os lineamentos maiores e preservadas no interior de estruturas adjacentes às curvaturas, offsets e splays existentes ao longo desses lineamentos. Essa relação espacial entre as rochas de cobertura e as estruturas maiores dos sistemas transcorrentes levaram diversos autores a sugerir que as rochas aqui definidas como Assembléia de Cobertura teriam sido depositadas em estruturas ou bacias transtensivas, ao longo dos sistemas transcorrentes Carajás e Cinzento (Siqueira 1990, Araújo \& Maia 1991). Estudos sedimentológicos e tectônicos efetuados por Nogueira (1995) e Pinheiro \& Holdsworth (1997a e $b$ ) têm mostrado que o modelo de bacias pull apart proposto para essas rochas é inconsistente com a estratigrafia e padrão das fácies observadas nas rochas do Grupo Grão Pará e Formação Águas Claras. Estudos de paleocorrentes realizados por Nogueira (1995) nas rochas da Formação Águas Claras indicam depocentro fora do atual domínio geográfico da bacia transtensiva anteriormente proposta. A presença de fácies marinhas dominadas por marés, afetadas por tempestades e regredindo para fácies fluviais, no contexto dessa mesma unidade, causa também dificuldades para entendê-la como depositada em regime sintectônico transtensivo. As rochas da Formação Águas Claras, por outro lado, mostram evidências de deposição em bacias amplas instaladas anteriormente à reativação destral que deu origem ao Sistema Transcorrente Carajás. Essa cinemática destral rúptil provocou subsidência localizada de parte dessas sequiências ao longo de zonas de dilatação extensional.

Pode-se ainda lembrar que os basaltos toleiíticos e formações ferríferas associadas ao Grupo Grão Pará são compatíveis com rochas observadas em bacias amplas, tais como aquelas do Transvaal (África do Sul) e Hamersley (Austrália), segundo Lindenmayer (1990).

Esse evento de subsidência com componente destral atribuído aqui à evolução da região pode ser ainda comprovado pela presença das rochas de cobertura em contato lateral brusco com rochas do embasamento, nos domínios da borda da estrutura sigmoidal de Carajás. A própria forma assimétrica em " $Z$ " dessa estrutura, como observada em imagem de sensores remotos, permite a interpretação desse evento transtensivo.

Transpressão Sinistral e Inversão: A Falha Carajás Parte das rochas da Assembléia de Cobertura, notadamente as rochas da Formação Águas Claras e do Grupo Grão Pará, está localmente deformada, desenvolvendo dobras e falhas. Essa deformação concentra-se, de modo restrito, em faixas subparalelas, em áreas adjacentes aos segmentos que formam a chamada Falha Carajás

A Falha Carajás é uma estrutura particular, com cerca de $130 \mathrm{~km}$ de comprimento, correspondendo a feixes de lineamentos curvilíneos a retos, entrelaçados, que em alguns locais alcançam até $4 \mathrm{~km}$ de largura, cortando obliquamente o Sistema Transcorrente Carajás no sentido aproximado ESE-WNW (Fig.3). Na terminação W dessa estrutura observam-se feixes em splay projetados para N-NE, seguindo-se de um segmento $\mathrm{E}-\mathrm{W}$ quase reto que inflete gradualmente para a direção WNW-ESE à altura do Rio Itacaiúnas, retornando à posição E-W até terminar em outro splay em "rabo-de-cavalo" desta vez com feixes projetados para S, na extremidade leste dessa falha (Fig.5).

Na parte central da Falha Carajás divergem feixes de lineamentos curvos NNW-SSE, côncavos para NE, que atravessam o bloco ao sul da falha, no centro da estrutura sigmoidal de Carajás. Esses lineamentos são cortados pelo Granito Central de Carajás (Fig.5).

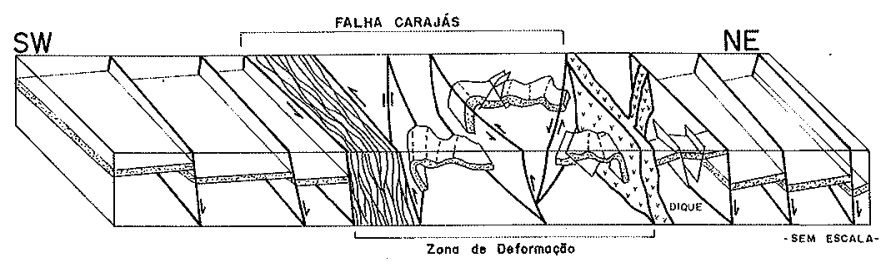

Figura 6-Bloco diagrama esquemático ilustrando a geometria das rochas na porção central do Sistema Transcorrente Carajás (região do Córrego Águas Clar(as; ver Fig. 3).

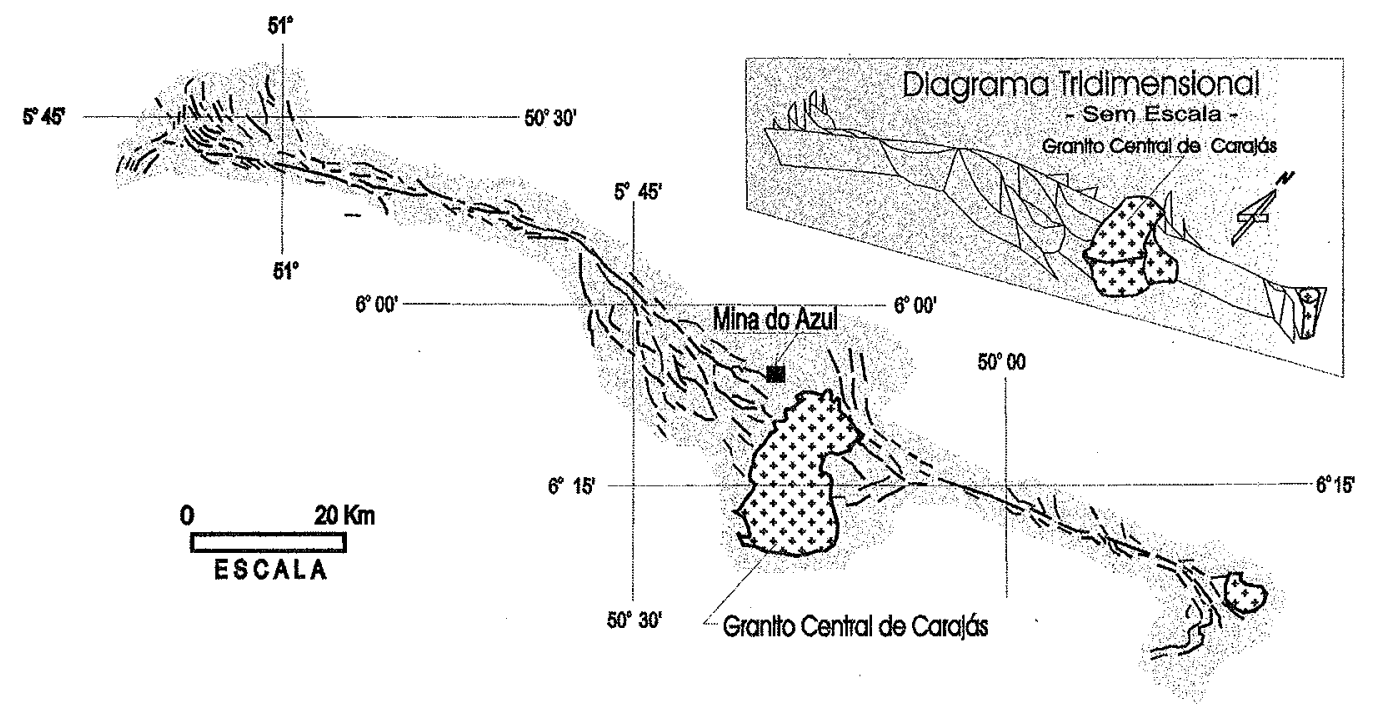

Figura 5 - Geometria da Falha Carajás, cortando obliquamente o Sistema Transcorrente Carajás (ver Fig. 3 para localização). 
Usando-se da geometria e orientação dos feixes de falhas projetados nas terminações dessa falha (no caso, o feixe projeta-se para NW, indicando extensão NE-SW), pode-se inferir que essa estrutura foi gerada em decorrência de cisalhamento transcorrente destral, provavelmente coevo com a subsidência da região central da estrutura de Carajás (após $2.7 \mathrm{Ga}$ )

Um importante segmento da Falha Carajás está exposto na estrada que liga a Mina do Igarapé Azul à Mina do Igarapé Bahia, cortando o Igarapé Águas Claras. Neste local afloram as fácies marinhas, transicionais e fluviais da Formação Águas Claras interrompidas por falhas normais NW-SE e N-S, espaçadas de 1 a $3 \mathrm{~km}$, formando cinco blocos maiores. Com base nas espessuras aflorantes das fácies mapeados, pode-se calcular um rejeito da ordem de $100-150 \mathrm{~m}$ para as falhas normais que definem esses blocos.

As rochas expostas no interior desses blocos, com exceção daquelas presentes nas adjacências do vale do Igarapé Águas Claras, encontramse pouco a não deformadas, sendo quase que exclusivamente afetadas por falhas isoladas e fraturas. $\mathrm{O}$ acamamento das rochas nesses blocos mergulha regularmente em torno de $20^{\circ}$ para $S W$.

As rochas presentes nas adjacências do córrego Águas Claras, onde passa um importante feixe de lineamentos associados à Falha Carajás, encontram-se pervasivamente deformadas (Fig.6). Em escala métrica essa deformação se traduz por dobras cônicas que mergulham com baixo ângulo para NW, por vezes assumindo padrões geométricos complexos com superposição de dobramentos (eixos e planos axiais subparalelos), eventualmente cortados por cavalgamentos oblíquos com mergulhos variáveis entre $20^{\circ}$ a $70^{\circ}$ (Holdsworth \& Pinheiro, 2000). Zonas de falhas maiores NW-SE e NE-SW dividem internamente esse bloco em padrões losangulares hectamétricos. A disposição dos elementos planares e lineares observados nas zonas de falha (a lineação tem comportamento variado nos planos das falhas) refletem uma cinemática transpressiva sinistral marcada por forte partição temporal e geométrica da deformação (Pinheiro 1997, Holdsworth \& Pinheiro, 2000).

Diques máficos, de idades ainda incertas, atravessam praticamente todas as rochas afloramentos da Formação Águas Claras na referida seção. Esses diques, em enxames, são observados como traços curtos $(2-5 \mathrm{~km}) \mathrm{NW}-\mathrm{SE}$, definindo uma textura com forte tropia unidirecional em sensores remotos, na parte central da estrutura de Carajás.

As rochas do Grupo Grão Pará aflorantes na região do platô N-4, norte do Sistema Transcorrente Carajás, encontram-se também localmente deformadas. A deformação afeta particularmente as rochas ferríferas e vulcânicas e se traduz principalmente em dobramentos que se dispõem em razão fractal, variando em escala desde centimétrica até quilométrica (Pinheiro \& Holdsworth 1997b). Na mina de N-4 predominam dobras decamétricas policlinais en echelon, desenhadas internamente por dobras menores, todas com eixo caindo com baixo ângulo para WNW. Essas dobras, em conjunto, terminam por projetar um par sinformal/antiformal quilométrico que desenha em mapa o " $\mathrm{S}$ " invertido que define grosseiramente o contorno do platô. A vergência de todas as dobras aponta para NE.

O platô N-4 é cortado na direção NNW-SSE por feixes de falhas, em forma de splay, que divergem para norte da Falha Carajás (Fig.3). Esses delimitam um bloco soerguido, onde afloram rochas do Grupo Grão Pará em contado lateral com rochas clásticas da Formação Águas Claras.

Segundo Pinheiro \& Holdsworth (1997b), a região do platô N-4 pode ser interpretada como uma zona soerguida durante o evento de transpressão sinistral associada à reativação da Falha Carajás, consecutivamente dobrada durante transpressão NE-SW contra um anteparo tectônico localizado no plano principal da falha, a SW, capaz de provocar a inversão do plano axial das dobras observadas, para NE. Evidências de transpressão sinistral estão marcadas pelo padrão da lineação mergulhando com baixo até alto ângulo nos contatos entre rochas ferríferas e vulcânicas. O metamorfismo que afetou as rochas é de grau baixo (xisto verde) a ausente, sendo comuns alterações hidrotermais.

\section{Os Granitos e Rochas Sedimentares do Proterozóico} Os lineamentos que compõem os sistemas transcorrentes Carajás e Cinzento, após sua formação em regime destral e reativação transpressiva sinistral, estiveram sujeitos ainda a pelo menos três outros eventos tardios de reativações tectônica, que serão discutidos a seguir. O primeiro deles ocorre durante Proterozóico Médio.
Durante o Proterozóico Inferior a Médio, o Cráton Amazônico esteve sob regime extensional com eixos de extensão dispostos entre NESW a E-W (Neves 1986, Costa et al. 1991, Brito Neves 1992). Esse evento de deformação tem sido apontado como responsável pelo extenso magmatismo anorogênico de idade $2.0-1.8 \mathrm{Ga}$ e pela deposição de rochas vulcânicas e sedimentares em bacias isoladas (ex. grupos Rio Fresco e Uatumã, no Rio Xingu) com desenvolvimento e reativação de falhas antigas (Issler et al 1985, Dall'Agnol et al. 1987, Sial et al. 1987, Teixeira 1990, Costa et al. 1991).

Na região de Carajás o magmatismo de idade $2.0-1.8 \mathrm{Ga}$ está bem representado por vários plútons graníticos (Fig.3), destacando-se o Granito Central de Carajás, na parte central do Sistema Transcorrente Carajás; o Granito Cigano, ao longo do Sistema Transcorrente Cinzento, além de inúmeros outros distribuídos na região da Serra do Rabo ( $\mathrm{E}$ do Sistema Transcorrente Carajás); ao N do platô N-4; na área do Igarapé Salobo; a NW do Sistema Transcorrente Carajás, nas proximidades do Rio Itacaiúnas (Dall'Agnol et al. 1987).

O estudo detalhado dessas rochas, envolvendo observações sobre a forma dos plútons, tipos de contatos, estruturas internas (foliação magmática, contatos entre fácies, veios, etc.) e nas encaixantes permite se entender a colocação desses corpos como tendo sido associado à extensão crustal, com eixos distensivos locais variando entre NE-SW, E-W e WNW-ESE. Sob tais condições, é provável que a entrada de magma tenha sido coeva, ou tardia, com a deformação rúptil das rochas encaixantes acompanhada por stoping, subsidência de caldeira e dyking (Pinheiro 1997).

$\mathrm{O}$ evento extensional regional NE-SW / E-W, que condicionou a intrusão dos corpos graníticos, pode ter reativado parcialmente os lineamentos E-W dos sistemas transcorrentes, por cisalhamento destral. Os granitos podem então ter sido colocados em zonas pull apart e outras feições dilatacionais, formadas durante esse episódio. A entrada desses corpos está associada a altas pressões de fluidos acompanhada por descargas ao longo de condutos tectônicos (fault-valve behaviour; Sibson 1987, 1994, Pinheiro 1997). Evidências para a ocorrência desse mecanismo de colocação podem ser encontradas na borda NW do Granito Central de Carajás, onde ocorrem hornfelses brechados que acompanham zonas de fraturas de tensão, com até 1-2m de largura.

Durante esse episódio de extensão NE-SW, os lineamentos E-W pré-existentes podem ter sido reativados em regime cinemático destral. Novas falhas normais $\mathrm{N}-\mathrm{S}$ eventualmente formadas podem ser observadas, por exemplo, ao longo da seção do vale do Córrego Águas Claras, cortando as rochas deformadas por transpressão sinistral associada à Falha Carajás (Fig.3). Essas falhas, com direção predominante N-S, podem variar para NNE-SSW e NE-SW.

Em contraste com as rochas sedimentares da Formação Águas Claras, constituídas predominantemente por rochas textural e composicionalmente maturas, formadas por (sericita-) quartzo arenitos, arenitos sublíticos e argilitos depositados em ambiente de plataforma marinha a litorânea e fluvial entrelaçado, ocorrem arenitos com baixa maturidade composicional e textural, predominando arcóseos grossos com abundantes estratificações cruzadas de porte médio a baixo, e conglomerados polimíticos, sem deformação aparente, com blocos e seixos de rochas incluindo granitos similares àqueles de idade 2.0 $1.8 \mathrm{Ga}$ que cortam as rochas da Formação Águas Claras (Granito Central de Carajás).

Esses arenitos, diferentes daqueles da Formação Águas Claras, ocorrem em locais restritos, com atitudes sub-horizontais, destacandose aqueles aflorantes a $\mathrm{E}$ do Rio Parauapebas, sendo ainda pouco estudados (Fig.3).

As características de depósitos de leques aluvionares, reconhecidas nessas rochas, associadas às tendências imaturas desses depósitos, e à sua aparente localização restrita, geralmente nas proximidades dos grandes lineamentos regionais (notadamente àqueles da Falha Carajás) pode indicar uma deposição condicionada por reativação tectônica desses lineamentos. Esse episódio de reativação pode corresponder à continuação daquele atribuído ao Proterozóico Médio, com caráter normal/destral, ou mesmo, estar relacionado a algum episódio mais jovem (Proterozóico Superior ?)

Reativações Tardias - o Fanerozóico Na região da Serra do Paredão, a NE do Sistema Transcorrente Cinzento, a cerca de $20 \mathrm{~km}$ a nordeste de Serra Pelada (Fig.3), ocorrem arenitos ortoquartzíticos avermelhados, finos a médios, associados com conglomerados polimíticos com seixos de quartzo e quartzito, com matriz caulinítica 
a illítica, apresentando estratificações cruzadas e marcas de onda, de origem fluvial (Figueiras \& Villas 1984, Ramos et al. 1984). Esses arenitos estão sobre gnaisses tonalíticos do embasamento, aflorantes nas adjacências da serra. Essas rochas estão em atitudes sub-horizontais, sendo cortadas por fraturas com ângulos de mergulhos altos e com direções predominantes NE-SW e N-S.

Em imagens de sensores remotos, a Serra do Paredão mostra uma forma triangular, limitada por fraturas com direções ENE-SSW, NWSE e N-S que controlam a ocorrência das rochas sedimentares descritas acima, tendo as rochas graníticas do embasamento em contato lateral (Fig.3).

Com base em estudos preliminares, observou-se a grande similaridade dessas sequêencias com aquelas do Paleozóico da Bacia do Parnaíba, notadamente do Grupo Serra Grande (Siluro-ordoviciana, Mabesoone 1978). Essas rochas tem sido associadas, de forma controversa, ao Grupo Rio Fresco (DOCEGEO 1988). Cabe ressaltar que a atual borda da Bacia do Parnaíba está aflorando a cerca de $150 \mathrm{~km}$ a leste da Serra do Paredão, e são reconhecidos grabens isolados preservando restos dessas seqüências paleozóicas a menos de $90 \mathrm{~km}$ a E e N desta região (Mabesoone 1978).

Os lineamentos que limitam as rochas sedimentares da Serra do Paredão são subparalelos às direções das estruturas principais dos sis. temas transcorrentes Carajás e Cinzento. Tratando-se de um graben preenchido com rochas paleozóicas, torna-se sugestivo que este esteja relacionado com a abertura do Atlântico Sul, durante o Mesozóico.

Os lineamentos principais que desenham os sistemas transcorrentes Carajás e Cinzento mostram ainda evidências de estarem presentemente ativos, destacando-se a presença de águas termais na região do Cururu, na parte central do Lineamento Cinzento (Fig.3), e ainda, a ocorrência de sismos de baixa intensidade, recentes, reportados por técnicos e trabalhadores da região do Igarapé Salobo (geólogo J. B. Siqueira, comunicação verbal). Costa et al. (1993), com base em dados sismológicos coletados durante a década de 90 , definiram uma zona sismogênica na região.

Reativação e História Tectônica Há evidências de que a orientação das estruturas regionais do embasamento, notadamente a trama milonítica arqueana presente nessas rochas, exerceu um importante papel no controle geométrico de estruturas geradas durante a atuação de eventos tectônicos posteriores, obedecendo a um processo de herança estrutural. ão:

Os critérios mais relevantes que permitem defender esta afirmativa

(1) a geometria dos sistemas transcorrentes, formando figuras sigmoidais em " $Z$ " (Sistema Transcorrente Carajás), em sidewall ripout, romboédros simétricos e terminações em "rabo-de-cavalo" (por ex. Sistema Transcorrente Cinzento), acompanha o mesmo arranjo anastomosado e entrelaçado da foliação milonítica presente nas rochas do embasamento. No interior dessas estruturas preservam-se restos de seqüências vulcânicas e sedimentares de diferentes idades, expostas em níveis variáveis, de acordo com a magnitude da subsidência associada a cada estrutura. A presença dessas unidades rochosas no interior dessas estruturas nos permite pensar na atuação de um evento transtensivo destral regional, posterior a cerca de $2.8 \mathrm{Ga}$ (idade de desenvolvimento da trama milonítica) e anterior a $2.6 \mathrm{Ga}$ (idade mínima para as rochas da Formação Águas Claras, Dias et al. 1996) responsável por esta configuração.

(2) a presença de estruturas de inversão tectônica, deformando localmente as rochas no interior das estruturas de abatimento desenvolvidas ao longo dos sistemas transcorrentes, registram novo evento deformacional ligado à reativação da Falha Carajás em particular: Existem critérios deformacionais e cinemáticos seguros para identificar esse evento como transpressional sinistral, com forte partição temporal e geométrica da deformação. A FaIha Carajás, nucleada nos estágios tardios do episódio de deformação anterior, foi a principal estrutura reativada. Esse evento teve lugar entre cerca de $2.6 \mathrm{Ga}$ e $2.0-1.8 \mathrm{Ga}$. A deformação das rochas da Formação Águas Claras e do Grupo Grão Pará, nas adjacências de feixes da Falha Carajás, está vinculada a esse episódio.

(3) o evento crustal regional que afetou o Craton Amazônico durante o Proterozóico Inferior a Médio, com eixos de extensão orienta- dos a NE-SW / E-W, responsável pela intrusão de plútons graníticos e diques e pelo desenvolvimento de fraturas com orientações N-S, NE-SW, NW-SE, deve ter reativado os lineamentos $\mathrm{E}-\mathrm{W}$ maiores associados aos sistemas transcorrentes. No caso da região de Carajás, essa reativação pode ter ocorrido sob cinemática destral. Esse suposto episódio destral deve ter contribuído de forma importante para a abertura de espaços para percolação de magmas e na deposição de rochas clásticas imaturas nas adjacências de falhas reativadas.

Outro evento tectônico que demonstra a importância da trama milonítica como elemento controlador da geometria de estruturas tardias e que invocam processos de reativação ao longo dos sistemas transcorrentes, diz respeito ao desenvolvimento de grabens mesozóicos, onde provavelmente preservaram-se rochas paleozóicas (Serra do Paredão).

A reativação neotectônica dos grandes lineamentos exige ainda maiores estudos, mas mostra-se bastante provável como já discutido anteriormente (ver, por exemplo, Costa et al.1995).

Este conjunto de informações sugere que a região de Carajás sofreu um processo de enfraquecimento crustal de longo período. As fraturas, falhas e zonas de cisalhamento de baixa temperatura presentes nas rochas da região são na maioria paralelas a subparalelas às zonas de cisalhamento dúcteis de alta temperatura do embasamento. Isso sugere que um processo de strain softening ocorreu ao longo dessas estruturas capaz de fazer com que essas zonas passassem a controlar a geometria das estruturas tardias. As estruturas geradas durante os episódios de deformação tardios, ligados às reativações, estão geralmente associados com alterações hidrotermais, incluindo silicificação, cloritização, epidotização, etc. É possível que grande parte do potencial mineral da região esteja associado a esses processos tardios. Faltam, no entanto, estudos detalhados que permitam uma avaliação mais precisa da abrangência desse mecanismo. Sabe-se que a presença de fluidos ao longo de zonas rúpteis tem importante papel no "enfraquecimento" mecânico dessas estruturas, facilitando a reativação e propiciando a instalação de mineralizações (Sibson 1977).

CONSEQÜÊNCIAS DO QUADRO EVOLUTIVO NA ESTRATIGRAFIA Com base nos dados anteriormente expostos, torna-se pertinente fazer algumas considerações sobre o quadro estratigráfico da região. Cabe ressaltar que a proposta aqui apresentada reflete apenas as consequiências dos principais eventos tectônicos sugeridos para a região, e, certamente está ainda bastante vulnerável a reajustes provenientes de estudos mais detalhados que precisam ser ainda realizados

As rochas formadas em regime dúctil de alta temperatura, sob os domínios da aqui chamada Zona de Cisalhamento Itacailinas, responsável pelo desenvolvimento de uma trama milonítica, penetrativa, de alta temperatura, com idade entre cerca de $3.05 \mathrm{Ga}$ e $2.85 \mathrm{Ga}$ (Rodrigues et al. 1992, Machado et al. 1991), foram agrupadas na Assembléia do Embasamento (Fig.3). Essa unidade reúne as rochas do chamado Complexos Pium (ortognaisses granulíticos); Complexo Xingu (anfibolitos, migmatitos, granodioritos e tonalitos metamorfizados - fácies anfibolito alto) e granitóides sintectônicos (ex. Suíte Plaquê, Araújo \& Maia 1991), reunidas no aqui denominado Complexo Granítico-Gnáissico. Existem ainda ocorrências isoladas de rochas supracrustais de alto grau (rochas vulcano-sedimentares do Grupo Igarapé Salobo; 2,76 Ga; Lindenmayer 1990, Machado et al.1991). Essas rochas estão também deformadas em zonas de cisalhamento dúctil, E-W, associadas à Zona de Cisalhamento Itacaiúnas, metamorfisadas em alto grau.

O Complexo Granítico-Gnáissico ocupa grande parte da região ao $\mathrm{N}$ e $\mathrm{S}$ dos sistemas transcorrentes e entre os mesmos (Fig.3). O Grupo Igarapé Salobo aflora na terminação W do Sistema Transcorrrente Cinzento, em enclaves sigmoidais, rodeados por rochas do Complexo Granítico-Gnáissico, limitados por lineamentos retos ou curvos, interpretados aqui como falhas oblíquas ou direcionais. Essas rochas são inferidas como tendo sido depositadas em discordância sobre aquelas do Complexo Granítico-Gnáissico, anteriormente ao evento transpressivo dúctil responsável pela deformação das rochas ao longo da Zona de Cisalhamento Itacaiúnas (cerca de $2.85 \mathrm{Ga}$ ).

As rochas vulcânicas e sedimentares, posteriores à formação das rochas da Assembléia do Embasamento, foram reunidas na Assembléia de Cobertura (Fig.3). Essa assembléia é representada por rochas vul- 
cânicas e sedimentares de baixo a muito baixo grau metamórfico, em discordância sobre as rochas do embasamento. As rochas arqueanas, representadas por metavulcânicas e sequêencias clásticas metamorfisadas em fácies xisto verde do Grupo Igarapé Pojuca (DOCEGEO 1988), estão em discordância sobre as rochas do embasamento e estão recobertas parcialmente por rochas vulcânicas e formações ferríferas menos deformadas que sofreram metamorfismo de muito baixo grau, ou mesmo não metamorfizadas, do Grupo Grão Pará (2.76 Ga; Wirth et al. 1986, Machado et al. 1991). Estas, por sua vez, estão recobertas parcialmente por sequiências de rochas sedimentares clásticas não metamorfizadas, depositadas em ambiente regressivo, de marinho raso plataformal a fluvial entrelaçado (Formação Águas Claras; Nogueira 1995).

As rochas da Assembléia de Cobertura estão preservadas ao longo de estruturas dilatacionais formadas ao longo dos sistemas transcorrentes Carajás e Cinzento (Fig.3). O metamorfismo e deformação presentes nestas rochas são predominantemente de baixa temperatura e do tipo rúptil-dúctil a rúptil, estando elas fortemente afetadas por hidrotermalismo, evidenciado em diferentes episódios (Lindemayer 1990).

O Grupo Igarapé Pojuca aflora ao longo da borda norte do Sistema Transcorrente Carajás e a leste do Sistema Transcorrente Cinzento, nas áreas adjacentes ao Igarapé Pojuca, ao Cururu e Serra Pelada. Ocorre ainda no Igarapé Bahia no Sistema Transcorrente Carajás, (Fig.3). O contato entre o Complexo Xingu o Grupo Igarapé Pojuca é marcado por uma discordância exposta na região de Serra Pelada. O Grupo Igarapé Pojuca está dobrado de modo penetrativo.

O Grupo Grão Pará está exposto ao longo das bordas $\mathrm{N}$ e S do Sistema Transcorrente Carajás e na região da Serra do Rabo (Fig.3). O contato do Grupo Grão Pará com o Grupo Igarapé Pojuca não é observado diretamente no campo, mas é presumivelmente discordante com base no padrão de deformação descrito para as rochas dessas unidades e nas diferenças de grau metamórfico. O contato entre o Grupo Grão Pará e as rochas da Formação Águas Claras é também, provavelmente, em discordância baseado em diferenças de estilo deformacional e grau metamórfico.

A Formação Aguas Claras está exposta em toda a região central do Sistema Transcorrente Carajás, recobrindo rochas dos grupos Pojuca e Grão Pará (Fig.3).

O Complexo Granítico Estrela (Barros 1997) está intrudido nas rochas do Grupo Grão Pará e Complexo Granítico-Gnáissico, NE do Sistema Transcorrente Carajás. A idade dessa granitogênese, associada a um episódio tectônico compressivo coaxial N-S (Barros 1997), é aceita como sendo de cerca de $2.5 \mathrm{Ga}$. Esta granitogênese, cuja extensão e ocorrência regional é ainda pouco conhecida, incluindo o Granito Old Salobo (Lindenmayer 1990), é responsável por alterar termalmente, de modo importante, as rochas encaixantes atribuídas ao Grupo Grão Pará.

Tanto as rochas da Assembléia do Embasamento quanto aquelas da Cobertura estão intrudidas por diques e granitos de idade em tomo de 2.0-1.8Ga, tais como o Granito Central de Carajás, o Granito Cigano e outros (Fig.3).

A seqüência clástica imatura, não deformada, que aflora a $\mathrm{E}$ do Rio Parauapebas e em locais restritos recobrindo as rochas supracrustais do Sistema Transcorrente Carajás, são aqui tratadas preliminarmente como Formação Gorotire. Essas rochas são supostamente de idade proterozóica média, ou mais jovens. A denominação "Gorotire" foi escolhida provisoriamente, no sentido de se evitar a introdução de novos nomes no quadro estratigráfico regional. O nome foi adotado de trabalhos anteriores que já levantam suspeitas de uma unidade sedimentar distinta, mais jovem, que aquelas hoje correlacionáveis à Formação Águas Claras (ex. Beiseigel et al. 1973, Hirata et al. 1982).

Tabela I - Sumário da história geológica sugerida para os sistemas transcorrentes Carajás e Cinzento na região de Serra dos Carajás (PA).

\begin{tabular}{|c|c|c|}
\hline Idade (Ga) & Evento & Cinemática \\
\hline \multirow{3}{*}{$0.24-0.15$} & $\begin{array}{l}\text { Reativação dos sistemas de falhas registrada } \\
\text { Por atividades sísmicas de baixa intensidade. }\end{array}$ & Desconhecida \\
\hline & $\begin{array}{l}\text { Reativação dos sistemas de falhas durante a } \\
\text { Abertura do Proto-Atlântico, no Mesozoico }\end{array}$ & Extensão \\
\hline & $\begin{array}{l}\text { Deposição de rochas paleozóicas } \\
\text { (Siluro-Ordoviciano) }\end{array}$ & Extensional (Bacia do Parnaíba) \\
\hline \multirow[t]{2}{*}{1.9} & Intrusão de plútons graníticos e diques & Extensão (ou Transtensão) \\
\hline & $\begin{array}{l}\text { Inversão tectônica fraca por reativação de } \\
\text { Falhas. Deformação moderada a forte das } \\
\text { Rochas adjacente à Falha Carajás. }\end{array}$ & $\begin{array}{l}\text { Transpressão Sinistral } \\
\text { (Falhas transcorrentes, inversas e dobramentos) }\end{array}$ \\
\hline \multirow[t]{4}{*}{2.6} & Desenvolvimento dos sistemas transcorrentes & Transtensão destral \\
\hline & $\begin{array}{l}\text { Carajás e Cinzento. Sequiências supracrustais } \\
\text { Falhadas e preservadas em zonas de } \\
\text { Subsidência ao longo dos sistemas de falhas. }\end{array}$ & $\begin{array}{l}\text { Falhas transcorrentes E-W e NW-SE e falhas normais } \\
\text { contornando blocos losangulares. }\end{array}$ \\
\hline & Nucleação da Falha Carajás. & \\
\hline & Deposição da Formação Águas Claras. & \\
\hline \multirow[t]{2}{*}{2.7} & $\begin{array}{l}\text { Deposição e derrames das rochas } \\
\text { vulcânicas e ferríferas do Grupo Grão } \\
\text { Pará, afetadas Posteriormente por } \\
\text { metamorfismo e/ou Hidrotermalismo em } \\
\text { grau muito baixo (após } 2.76 \mathrm{Ga} \text { ). }\end{array}$ & $\begin{array}{l}\text { Extensão } \\
\text { Amplas bacias intracratônicas }\end{array}$ \\
\hline & $\begin{array}{l}\text { Rochas do Grupo Igarapé Pojuca foram } \\
\text { Afetadas por metamorfismo e deformação } \\
\text { Dúctil de temperatura média a baixa. }\end{array}$ & $\begin{array}{l}\text { Transpressão Sinistral } \\
\text { (Zonas de cisalhamento sinistrais e dobramentos) }\end{array}$ \\
\hline 2.8 & $\begin{array}{l}\text { Zona de Cisalhamento Itacaiúnas. Deformação } \\
\text { Dúctil de temperatura alta afetando as rochas da } \\
\text { Assembléia do Embasamento. }\end{array}$ & $\begin{array}{l}\text { Transpressão Sinistral } \\
\text { (Forte partição da deformação) }\end{array}$ \\
\hline
\end{tabular}




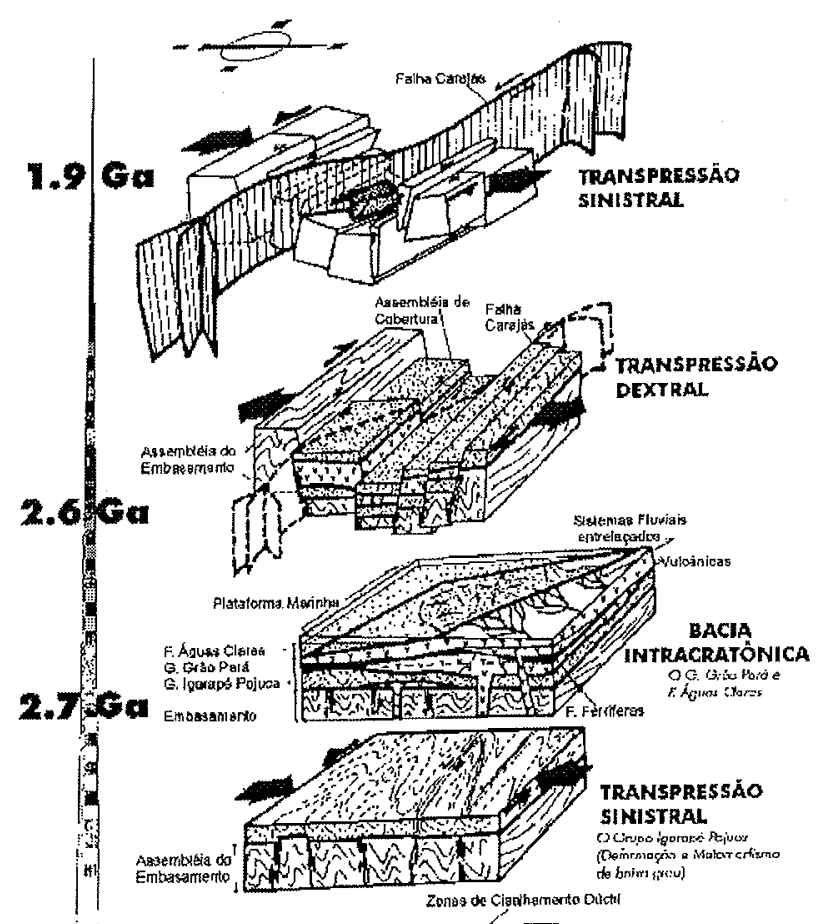

$2.8 \mathrm{Ga}$

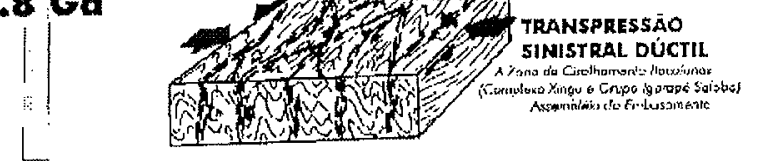

Figura 7 - Qradro evolutivo esquemático para a região de Carajás, no período $2.8 \mathrm{Ga}$ a $1.9 \mathrm{Ga}$. Veja texto para detalhes.

As rochas da Serra do Paredão, a NE da região de Serra Pelada, foram aqui correlacionadas com o Grupo Serra Grande, do SiluroDevoniano da Bacia Sedimentar do Parnaíba (Fig.3). Elas são distintas daquelas da Formação Águas Claras e da aqui chamada como Formação Gorotire, representando as rochas mais jovens na estratigrafia da região.
CONCLUSÕES A história tectônica aqui proposta para a região de Carajás ( Tabela I e Fig.7), permite concluir que:

1 As rochas arqueanas da região de Carajás preservam evidências de atividades tectônicas por mais de $2.8 \mathrm{Ga}$, onde a trama dúctil de alta temperatura desenvolvida nas rochas do embasamento foi reativada diversas vezes, exercendo influência decisiva na distribuição, padrão geométrico e cinemática das estruturas posteriormente formadas.

2 A trama milonítica de alta temperatura do embasamento tem orientação E-W, com mergulhos fortes para N e S. Subsequentes etapas de reativações rúpteis dessa trama foram dominadas preferencialmente por transcorrências, em lugar de reativações ao longo do mergulho, provavelmente devido a sua atitude com ângulos de mergulhos altos. Casos similares têm sido registrados na literatura, em áreas semelhantes (p. ex. Etheridge 1986).

3 A influência do controle geométrico das estruturas mais antigas sobre o desenvolvimento de novas estruturas toma-se gradativamente menor após cerca de $1.8 \mathrm{Ga}$. A partir desse momento observa-se uma diminuição progressiva da intensidade da deformação, com o desenvolvimento de novas fraturas com orientações próximas a N-S, indicando que a capacidade de reativação das estruturas mais antigas passou a ser mecanicamente desfavorecida.

4 A localização das rochas vulcânicas e sedimentares da Assembléia de Cobertura está controlada por falhas direcionais a oblíquas. A maioria dessas rochas de cobertura está preservada em zonas de subsidência (dilational jogs), trechos anastomosados ou em offsets, ao longo dos feixes de lineamentos que formam os sistemas transcorrentes Carajás e Cinzento. Essas falhas, ou feixes de falhas, são posteriores à deposição dessas seqüências. Nesse caso, a estratigrafia é controlada pelas falhas e, portanto, as falhas não controlam a sedimentação ou o desenvolvimento de bacias.

5 As observações indicam a existência de um mecanismo de enfraquecimento crustal, em escala litosférica, com um período de atividade finito, mais ativo entre $2.8-1.8 \mathrm{Ga}$, originado possivelmente na crosta inferior ou no manto. Comportamentos similares da crosta têm sido observados em outras regiões cratônicas (p. ex. Etheridge 1986).

Agradecimentos À CAPES por financiar bolsa de doutorado na Inglaterra para o primeiro autor; à Companhia Vale do Rio Doce pelo suporte financeiro de parte do projeto de tese; à DOCEGEO LTDA, ao Departamento de Geologia (Centro de Geociências, UFPa) pelo apoio durante os trabalhos de campo e a dois relatores da RBG pelas sugestões e críticas.

\section{Referências}

Araújo OJB. \& Maia RGN. 1991. Projeto especial mapas de recursos minerais, de solos e de vegetucão para a área do Programa Grande Carajás; Subprojeto Recursoss e de vegetucáo para a area do Programa Grande Carajas: Suthprojeto Recursoss
Minertis: Foltha SB.22-Z-A Serra dos Carajas - Estado do Pará. DNPM/CPRM, Minerctis; Folh

Barbosa O, Ramos JRA, Gomes FA, Helmont R. 1966. Geslogia estrutigraficica, estrutural e econômica da área do "Projeto Araguatia". Monografia da DGM, Rio de Janeiro, $94 \mathrm{p}$.

Barros CEM 1991. Evolução petrológica e estrutural do Gnaisse Estrela, Curionópolis, PA. Dissertação de Mestrado. Universidade Federal do Pará, Curso de Pós-Graduação em Geociências, Belém, 134p.

Barros CEM 1997. Pétrologie et structure du Complexe Granitique Estrela (2.5GA) et de son encaissant métavolcano-sédimentaire (Province Métallifêre de Carajás, Brésil). Tese de Doutorado. Université Henri Poincaré, Centre de Recerches Pétrographiques et Géochimiques (CRPG-UPR9046), 316p.

Beisiegel VR, Bernadelli AL, Drummont NF, Ruff AW, Tremaine JW. 1973. Geologia e recursos minerais da Serra dos Carajás. Revista Brasileira de Geociênciass, 3, 215242.

Brito Neves BB.1986. Tectonic regimes in the Proterozoic of Brazil. Actas XII Simpásio de Gerlogia do Nordleste, Joño Pessoa, 235-251.

Costa JBS, Araújo OJB, Santos A, Jorge João XS, Macambira MJB, Lafon JM. 1995. A Província Mineral de Carajás: aspectos tectono-estruturais, estratigráficos e geocronológicos. Boletim do Museu Paraense Emilio Goeldi, 7:199-235.

Costa JBS, Pinheiro RVL, Jorge João XS, Araújo OJB. 1991. Esboco estrutural do Proterozóico Médio da Amazônia Oriental. Boletim do Museu Paraense Enilito Goeldi, Série Ciências da Terra, 3, 9-24.

Costa JBS, Hasui Y, Bemerguy RL, Borges MS, Costa AR, Travassos W, Mioto JÁ, lgreja HLD. 1993. Aspectos fundamentais da neotectônica na Amazônia Brasileira. 1

Dall' Agnol R, Bettercourt JS, João XSI, Medeiros H, Costi HT, Macambira MJB. 1987. Granitogenesis in northern Brazilian region: a review. Revista Brasileira de Geologia, 17:382-403.
Dias GS, Macambira MJB, Dall'Agnol R, Soares ADV, Barros CE. 1996. Datação de zircões de sill de metagabro: comprovação da idade arqueana da Formaçāo Aguas
Claras, Carajás - Pará. V Simpósisio de Geologia da Amazôniat, SBG-NO, Boletim de Resumos Expadidos, Belém, 376-379.

DOCEGEO 1988. Revisão litoestratigráfica da Província Mineral de Carajás. Anciis XXXV

Congresso Brasileiro de Geologia, anexo, Belém, 10-54.
Etheridge MA 1986. On reactivation of extensional fault systems. Philosophical Transactions of the Royal Society of London, A317, 179-194.

Ferreira Ir CAP 1993 Relaçes estruturais entre o Terreno Grantio-Greenstone do Sul do Pará e o Cinturão de Cisalhamento Itacaiúnas na regiño de Xingusara, sudeste do estado de Pará. Trabalho de Conclusão de Curso, UFPa, Departamento de Geologia, Belém, 116p.

Figueiras AJM \& Villas RNN. 1984. Estudo petrológico e sedimentológico da sequência clástica (Pós-Grupo Grão Pará) da Serra dos Carajás, Estado do Pará. Anais XXX Conngresso Brasileiro de Gerlogia, Rio de Janeiro, 2, 832-846.

Fossen H \& Tikoff B. 1993. The deformation matrix for simultaneous simple shearing, pure shearing and volume change, and its application to transpression-transtension tectonics. Journal of Structural Geology; 15:413-422.

Gibbs AK Wirth KR Hirata WK, Olszewski Ir: WJ. 1986. Age and composition of the Grão Pará Group volcanics, Serra dos Carajás. Revista Brasileira de Geociências, Grão Pará GR

Hirata WK, Rigon JC, Cordeiro AAC, Meireles EM. 1982. Geologia regional da Província Mineral de Carajás. Anais I Simprósio de Geologia da Amazônia, Belém, 100-108.

Holdsworth RE \& Pinheiro RVL. 2000. The anatomy of shallow-crustal transpressional structures: insights from the Archaean Carajás fault zone, Amazon, Brazil. Journal of Structural Geology 22:1105-1124.

Issler RS, Freire FA, Santos ROB.1985. O Plutonismo intraplaca do Cráton Amazônico no intervalo de tempo de 1800 a 900 M.A. Ancis II Simpósio de Geologia da Amazônia, Belém, 2, 53-72

Johnson TE, 1991. Nomenclature and geometric classification of cleavage-transected folds Journal of Structural Geology; 12:261-274. 
Lab KL. 1992. Consideraçóes lito-estuturais sobre o Duplex Transpressivo Serra Pelada. Dissertação de Mestrado, Universidade Federal do Pará, Curso de Pós-graduacão em Geociências, Belém, $109 \mathrm{p}$.

Lindenmayer ZG. 1990. Salobo Sequence, Carajás, Brasil: geology, geochemistry and metamorphism. Tese de Doutorado, University of Western Ontatio, Canadá, 407p.

Mabesoone JM. 1978. Origem dos conglomerados da Formação Serra Grande e unidades equivalentes (Siluriano Superior Devoniano Inferior, Nordeste do Brasil). XXX Conresso Brasileiro de Geologia, Anais, Recife, 2, 799-808

Macambira EMB, Vale AG, Jorge João XS, Costa JBS. 1994. O quadro geológico da Folha São Félix do Xingu (SB.22-Y-B). Anais $38^{\circ}$ Congresso Brasileiro de Geologia, Balneário de Camboriú, 111-112.

Machado W, Lindenmayer Z, Krogh TE, Lindenmayer D. 1991. U-Pb geochronology of Archean magmatism and basement reactivation in the Carajás área, Amazon shield, Brazil. Precambrian Research, 49:29-354.

Marçal MS. 1991. Aspectos lito-estruturais das minas de Ferro N4E e Manganês do Azu Serra dos Carajás (PA). Dissertação de Mestrado. Universidade Federal do Pará, Curso de Pós-Graduação em Geociências, Belém, 135p.

Medeiros Neto FA. 1985. Estudos geológicos, geoquímicos e microtermométricos da Jazida de Sulfeto de Cu-Zn do Corpo 4-E/Pojuca, Serra dos Carajás. Dissertação de Mestrado, Universidade Federal do Pará, Curso de Pós-Graduação em Geociências, Belém, 168p.

Meireles EM Hirat WK Amaral AF Medeiros Fitho CA Gato WC 1984 Geologia das Folhas Carajás e Rio Verde, Província Mineral dos Carajás, Estado do Pará Anai XXXI Cario

Nogueira ACR. 1995. Análise faciológica e aspectos estruturais da Formação Águas Cla ras, Região Central da Serva dos Carajás - Pará. Dissertação de Mestrado, Universidade Federal do Pará, Curso de Pós-Graduação em Geociências, Belém, 167p.

Pinheiro RVL. 1997. Reactivation history of the Carajás and Cinzento Strike Slip System. Amazon, Brazil. Tese de Doutorado, Durham, Inglaterra, 408p.

Pinheiro RVL \& Holdsworth RE. 1995. Significado tectônico da clivagem transversa (transecting cleavage) em dobras na Mina de Serra Pelada, Pará. Boletim do Museu Paraense Emilio Goeldi, Série Ciências da Terra, 7, 259-278.

Pinheiro RVL \& Holdsworth RE 1997 a. Reactivation of Archean strike-slip fault systems, Amazon region, Brazil. Joumal of the Geological Society, 154:99-103.
Pinheiro RVL \& Holdsworth RE. 1997b. The structure of the Carajás N-4 ironstone deposit and associated rocks: relationship to Archaean strike-slip tectonics and basement reactivation in the Amazon region, Brazil. Journal of South American Earth Sciences; 10:305-319.

Rego LFM. 1933. Notas geográficas e geológicas sobre o Rio Tocantins. Boletim do Museu Emílio Goeldi da História Natural e Etnologia, Belém, 9, 272-288.

Rodrigues ES, Lafon JM, Scheller T. 1992 Geocronologia Pb-Pb da Província Mineral de Carajás: primeiros resultados. 37 Congresso Brasileiro de Geologia, Boletim de Carajás: primeiros resultados. 37 Congresso

Sial AN, Oliveira EP, Choudhuri A. 1987. Mafic Dyke Swarms of Brazil, Geological Association of Canadá, Special Paper, 34:467-481.

Sibson RH. 1977. Fault rocks of the Moine Thrust Zone. Texture and microestructures Journal of the Geological Society, London, 133:191-213.

Sibson RH. 1987. Earthquake rupturing as a hydrothermal agent. Geology, 13:701-704.

Sibson RH. 1994. Crustal stress, faulting and fluid flow. In Parnell J. (Ed.) Geofluids: origin, migration and evolution of fluids in sedimentary basins. Geological Society Special Publication, 78:69-84

Siqueira JB. 1990. Organizacão lito-estrufural do duplex Salobo-Mirim, Serra dos Carajás. Dissertação de Mestrado, Universidade Federal do Pará, Curso de PósGraduação em Geociências, Belém, 125p.

Teixeira W. 1990. The Proterozoic mafic dyke swarms and alkaline intrusions in the Amazonian Craton, South America, and their tectonic evolution based on $\mathrm{Rb}-\mathrm{Sr}, \mathrm{K}$ Ar and 40Al-39Ar geochronology. In Parker, Rickwood and Tucker (ed), Mafic Dykes and Enplacement Mechanisms, Balkema, Rotterdam, 285-293.

Wirth KR. 1986 The geolon and geachenistry of the Grão Pará Group Serra dos Carajós. Pará, Brazil. Disserlacão de Mestrado, Cornell, Ithaca, New York, 284p.

Wirth KR, Gibbs AK, Olszewski Jr. 1986. U-Pb ages of zircons from the Grão-Pará Group and Serra dos Carajás Granite, Pará, Brazil. Revista Brasileira de Geociências, 16:195-200.

Manuscrito A-1078

Recebido em 12 de marco de 1999

Revisão dos autores em 20 de agosto de 2000 Revisão aceita em 25 de agosto de 2000 